Received, Maret 2020

Revised, September 2020

Accepted, July 2021

https://ejournal.unperba.ac.id/index.php/pijeb

\title{
IMPACT OF THE COMPANY'S SERVICE QUALITY DIMENSION ON CUSTOMER CUSTOMER SATISFACTION AT IMALEZ MULTY CORP COOPERATIVE
}

\author{
Reza Rahmadi Hasibuan"1, R. Satria Setyanugraha ${ }^{2}$ \\ Universitas Perwira Purbalingga \\ rezarahmadi@unperba.ac.id
}

\begin{abstract}
The purpose of this study is to examine the effect of the relationship between reliability, responsiveness, assurance, empathy and physical evidence of satisfaction at effect of service quality dimension on customer satisfaction in imalez multy corp. The results show that reliability has no significant effect on satisfaction, this is evidenced by the sig value. the count is greater than 0.05, ie 0.669>0.05. Responsiveness has a significant effect on satisfaction, this is evidenced by the sig value. the count is smaller than 0.05, ie $0.011<0.05$. Warranty has no significant effect on satisfaction, it is proved by sig value. the count is greater than 0.05, ie $0.985>0.05$. Empathy has no significant effect on satisfaction, this is proved by the sig value. the count is greater than 0.05, ie 0.438>0.05. Physical evidence has a significant effect on satisfaction, this is evidenced by the sig value. the count is smaller than 0.05, ie 0.019<0.05.
\end{abstract}

Keywords: reliability, responsiveness, assurance, empathy, physical evidence and satisfaction.

\section{INTRODUCTION}

The complete consumer experience of a product's ability to meet their needs, according to Kotler (1995:42). The question "what agency or company exists?" leads to the creation of an agency or mission mission firm. Of course, the existence of an institution or company is linked to the product or the benefits it provides to the community or market it serves. This mission statement is also inseparable from the efforts of agencies or companies to meet the needs and anticipate problems that can accommodate them. In the economy, people need financial institutions that can lend them money.

With this loan money people can do economic activities to improve their standard of living. If there are no financial institutions in the community, those who need borrowed money will sell their goods or borrow money from loan sharks who often charge unreasonable interest. One form of loan money that can meet the needs of the community is credit made by cooperative financial institutions. Cooperatives are business entities consisting of cooperatives or legal entities by basing their activities on cooperative principles as well as people's economic movements based on family principles.

Koperasi bertujuan untuk improve the living standards of its members. In the Statement of Financial Accounting Standards (PSAK) No. 27 (Revised 1998) mentioned that the main characteristic of cooperatives that distinguish it from other business entities is that cooperative members have many identities. Dual identity means that the cooperative member is the owner and user of the cooperative service. Generally cooperatives are jointly controlled by all members, where each member has the same voting rights in every decision taken by the cooperative. Cooperative revenue sharing (commonly referred to as the remaining business results or SHU) is usually calculated based on the member's share in the cooperative, for example by distributing dividends based on 
the size of the purchase or sale made by the member. The cooperative was introduced in Indonesia by R. Aria Wiriatmadja in Purwokerto, Central Java in 1896. He founded a credit cooperative with the aim of helping his debt-stricgged people with leeches. Koperasi tersebut kemudian berkembang pesat dan akhirnya diadopsi oleh Boedi Oetomo dan SDI. The cooperative then developed rapidly and was eventually adopted by Boedi Oetomo and SDI.

Cooperative services are the spearhead of overall performance quality. This is because cooperatives are entities or institutions that depend on the type of service business. The increase in customers or the level of financial turnover of cooperatives comes from the quality of services provided to customers. The role of cooperative employees in good implementation, polite speech, service reliability and responsiveness to customer complaints, can attract people to become customers.

Customer satisfaction in this case is customer, not only because of the performance of the service, but also because of the financial burden imposed by the cooperative. However, it can be resolved if the treatment and service of employees given to customers is better, the satisfaction felt by customers depends on their perception of the expectations and quality of service provided by the company. Service quality is the way customers evaluate the level of service received (perceived service) with the expected service level. If customer expectations are higher than the level of service received, then the customer is not satisfied. Similarly, if expectations are equal to or less than the level of service received, the customer will be satisfied. Companies that do not satisfy their services will face complex problems, due to the impact of word of mouth. Generally, disgruntled customers will share their bad experiences with others and you can imagine how much it costs to unsatisfactory customers. Therefore, every service company must plan, regulate, implement and control the quality system in such a way that the service can satisfy its customers. The measure of success of a company dedicated to this field of service is the number of integrated clients. It is influenced by the extent to which the company can satisfy the wishes and satisfaction of its customers. If the performance of the services provided can meet or even exceed customer expectations, customer satisfaction will be achieved and more customers are integrated. Kotler (1995: 42) states that satisfaction is the level of feeling after comparing the performance you feel to your expectations. Therefore, the level of satisfaction is a function of the difference between perceived performance and expectations. If the performance is below expectations, the customer is not satisfied. If the performance is as expected, the customer will be very satisfied. And if the performance exceeds expectations, the customer will be very happy or very satisfied. The dimensions of service quality in this study are responsiveness, trustworthiness, security (assurance), empathy (attention), and tangibles (physical appearance).

Imalez Multy Corp. cooperative is one of the cooperatives in Purwokerto. Where the cooperative has the purpose to help the surrounding community in the system of saving loans. Here are the customer data from Imalez Multy Corp Cooperative in 2019:

Table 1. Number of Imalez Multy Corp. Cooperative customers in 2019

\begin{tabular}{|c|c|c|c|c|c|c|c|c|c|c|c|c|}
\hline \multirow{2}{*}{ Total } & \multicolumn{10}{|c|}{ Month } \\
\cline { 2 - 14 } & $\mathbf{1}$ & $\mathbf{2}$ & $\mathbf{3}$ & $\mathbf{4}$ & $\mathbf{5}$ & $\mathbf{6}$ & $\mathbf{7}$ & $\mathbf{8}$ & $\mathbf{9}$ & $\mathbf{1 0}$ & $\mathbf{1 1}$ & $\mathbf{1 2}$ \\
\hline Number & 302 & 397 & 486 & 472 & 432 & 398 & 361 & 342 & 332 & 318 & 301 & 296 \\
of & 4 & 4 & 8 & 0 & 9 & 4 & 8 & 7 & 1 & 7 & 5 & 7 \\
\hline
\end{tabular}




\begin{tabular}{|c|l|l|l|l|l|l|l|l|l|l|l|l|}
\hline $\begin{array}{c}\text { Custome } \\
\text { rs }\end{array}$ & & & & & & & & & & & \\
\hline
\end{tabular}

Source : Interview Results 2019

According to the table above, there was an increase in the first three months due to the fact that the Cooperative was only one year old, but there was a reduction from the fourth to the twelfth month. This is due to the fact that numerous cooperatives provide loans with lesser bunya than the Imalez Multy Corp. Cooperative.

\section{LITERATURE REVIEW \\ Customer Satisfaction}

The more consumers involved in meeting the needs and desires of consumers, the tighter competition forces companies to put orientation on customer satisfaction as the main goal. According to Phillip Kotler (2001: 36) states that satisfaction is the feeling of a person happy or disappointed that comes from a comparison between the impression of product performance and expectations..

Applying the right service patterns requires knowledge of multiple perceptions and responses from different consumers. Criteria for customer satisfaction for the services provided, consumers will be satisfied if the services offered by the company to consumers in accordance with expectations or exceed consumer expectations. In accordance with customer expectations or estimates called quality, in this case the quality of service.

\section{Service Quality}

The definition of service quality is centered on addressing the needs and desires of Kunsumen and the accuracy of delivery to keep pace with consumer expectations. According to Wyekof (quoted in Fandy Tjiptono 2000: 59), the definition of service quality is: the expected level of excellence and control over the level of excellence to meet the wishes of consumers. If the service received as expected, then the quality of service is felt good and satisfactory, if this service can be accepted beyond the expectations of consumers of ideal quality. Conversely, if the services received are lower than expected consumers, the quality is perceived to be poor. Thus the quality of service depends on the ability of service owners in meeting consumer expectations consistently but dynamically to follow the needs of consumers.

The quality of service has several dimensions, although between one service area and another service has some differences with regard to the dimensions that make up the quality of service, but some studies show similarities or similarities in the dimensions underlying the formation of quality services.

According to Parasuraman, (quoted in Fandy Tjiptono, 2000: 70) there are ten dimensions of service quality after statistical tests known as factor analysis, ten of these dimensions can be summarized into five dimensions:

a. Direct Proof (Tangibles)

Direct evidence includes sightings of facilities, buildings, equipment and the appearance of company employees. A company that has complete facilities and adequate buildings will affect the evaluation of consumers on the quality of services provided by the company. Consumers always try to assess services or services before they buy and services because they can't see the service itself, they will judge based on all objects related to the service itself.

b. Reliability

Reliability, shows how far service providers are able to deliver the same services or services as promised accurately and appropriately. Reliability is not only critical to very big issues, but often with small services it is also important for consumers to help evaluate whether high or low-quality service. As a result of poor service, companies will receive negative publicity and that leads 
to a decline in consumers who will buy services from the future.

c. Responsiveness

Responsiveness, showing the willingness and commitment of service providers to assist customers in providing services in a timely manner. Responsiveness is not only about the fast service provided, but also the willingness of service providers or employees in helping consumers

d. Assurance

Guarantees include: competence, decency, credibility (credibility) and security (security). Competence consists of the skills and knowledge of employees in providing services. Courtesy includes polite and friendly from employees to consumers.
Credibility concerns the reputation of the company.

e. Empathy (Emphaty)

Empathy includes: access, communication and under-standing customers. communication skills of employees to properly explain the services provided will have a positive impact on consumer assessment. The noteworthy thing to mention is to understand the wishes of consumers, this should not be underestimated.

By looking at the quality of service from several dimensions it is easy for companies to continuously monitor how well the quality of services or services provided to consumers

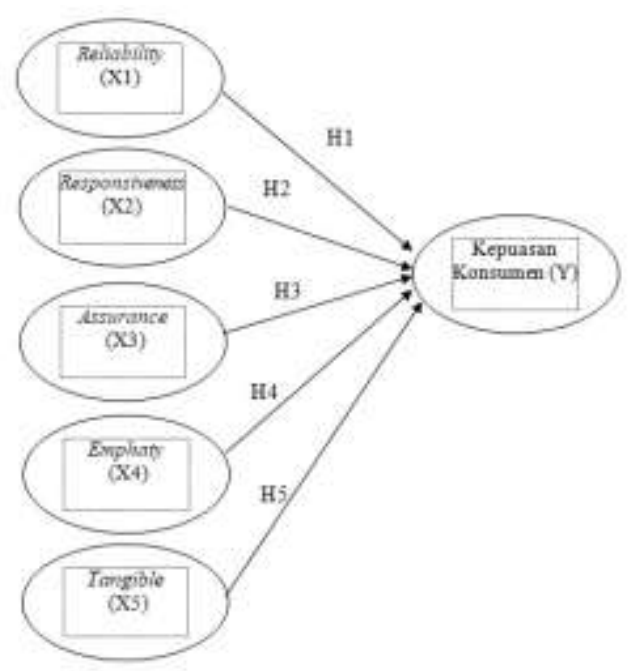

Figure 1. Conceptual Framework

\section{RESEARCH METHODS}

The research has a population of 2,967 customers from the Imalez Multy Corp. Cooperative. The number of samples in this study was 100 respondents.

Data collection using a list of questions provided to answer questions in writing by respondents. Questionnaires contain questions, each question opens a chance of a possible five. Out of the five answers, respondents are expected to choose one of the answers that is considered the most appropriate for him. Each answer has a score score, where 1 strongly disagrees until 5 strongly agrees.

Multiple Linear Regression Tests were used in this study to analyze and and use SPSS Software 
RESULT AND DISCUSSION

Hasil

\section{Uji Validitas}

Tabel 3. Correlation Pengujian Validitas

\begin{tabular}{|c|c|c|c|}
\hline Variabel/Item & r Hitung & R Tabel (Two Tale) & Valid / Tidak \\
\hline \multicolumn{4}{|l|}{ Variabel X1 } \\
\hline $\mathrm{X} 1.1$ & 0,782 & 0,1966 & Valid \\
\hline $\mathrm{X} 1.2$ & 0,867 & 0,1966 & Valid \\
\hline $\mathrm{X} 1.3$ & 0,806 & 0,1966 & Valid \\
\hline \multicolumn{4}{|l|}{ Variabel X2 } \\
\hline $\mathrm{X} 2.1$ & 0,860 & 0,1966 & Valid \\
\hline $\mathrm{X} 2.2$ & 0,900 & 0,1966 & Valid \\
\hline $\mathrm{X} 2.3$ & 0,876 & 0,1966 & Valid \\
\hline \multicolumn{4}{|l|}{ Variabel X3 } \\
\hline X3.1 & 0,800 & 0,1966 & Valid \\
\hline $\mathrm{X} 3.2$ & 0,807 & 0,1966 & Valid \\
\hline X3.3 & 0,761 & 0,1966 & Valid \\
\hline \multicolumn{4}{|l|}{ Variabel X4 } \\
\hline $\mathrm{X} 4.1$ & 0,721 & 0,1966 & Valid \\
\hline $\mathrm{X} 4.2$ & 0,881 & 0,1966 & Valid \\
\hline $\mathrm{X} 4.3$ & 0,847 & 0,1966 & Valid \\
\hline \multicolumn{4}{|l|}{ Variabel X5 } \\
\hline X5.1 & 0,859 & 0,1966 & Valid \\
\hline $\mathrm{X} 5.2$ & 0,875 & 0,1966 & Valid \\
\hline X5.3 & 0,861 & 0,1966 & Valid \\
\hline \multicolumn{4}{|l|}{ Variabel Y } \\
\hline Y1.1 & 0,810 & 0,1966 & Valid \\
\hline Y1.2 & 0,854 & 0,1966 & Valid \\
\hline Y1.3 & 0,840 & 0,1966 & Valid \\
\hline
\end{tabular}

From the test results above, all question indicators are said to be valid so that the test can be continued to the next stage

\section{Uji Reliabilitas}

Tabel 4. Reliability Pengujian Kuesioner

\begin{tabular}{ccc} 
Variabel & $\begin{array}{c}\text { Nilai Cronbach's Alpha } \\
\text { Based } \text { on Standardized } \\
\text { Item }\end{array}$ & Keterangan \\
X1.1 & 0,941 & \\
X1.2 & 0,935 & Reliabel \\
X1.3 & 0,934 & Reliabel \\
X2.1 & 0,935 & Reliabel \\
X2.2 & 0,935 & Reliabel \\
X2.3 & 0,938 & Reliabel \\
X3.1 & 0,935 & Reliabel \\
X3.2 & 0,936 & Reliabel \\
\hline
\end{tabular}




\begin{tabular}{lll}
\hline X3.3 & 0,937 & Reliabel \\
X4.1 & 0,936 & Reliabel \\
X4.2 & 0,936 & Reliabel \\
X4.3 & 0,937 & Reliabel \\
X5.1 & 0,934 & Reliabel \\
X5.2 & 0,935 & Reliabel \\
X5.3 & 0,935 & Reliabel \\
Y1.1 & 0,938 & Reliabel \\
Y1.2 & 0,934 & Reliabel \\
Y1.3 & 0,935 & Reliabel \\
\hline
\end{tabular}

From the analysis, cronbach's alpha value was above 0.600 , meaning the

\section{Uji Normalitas}
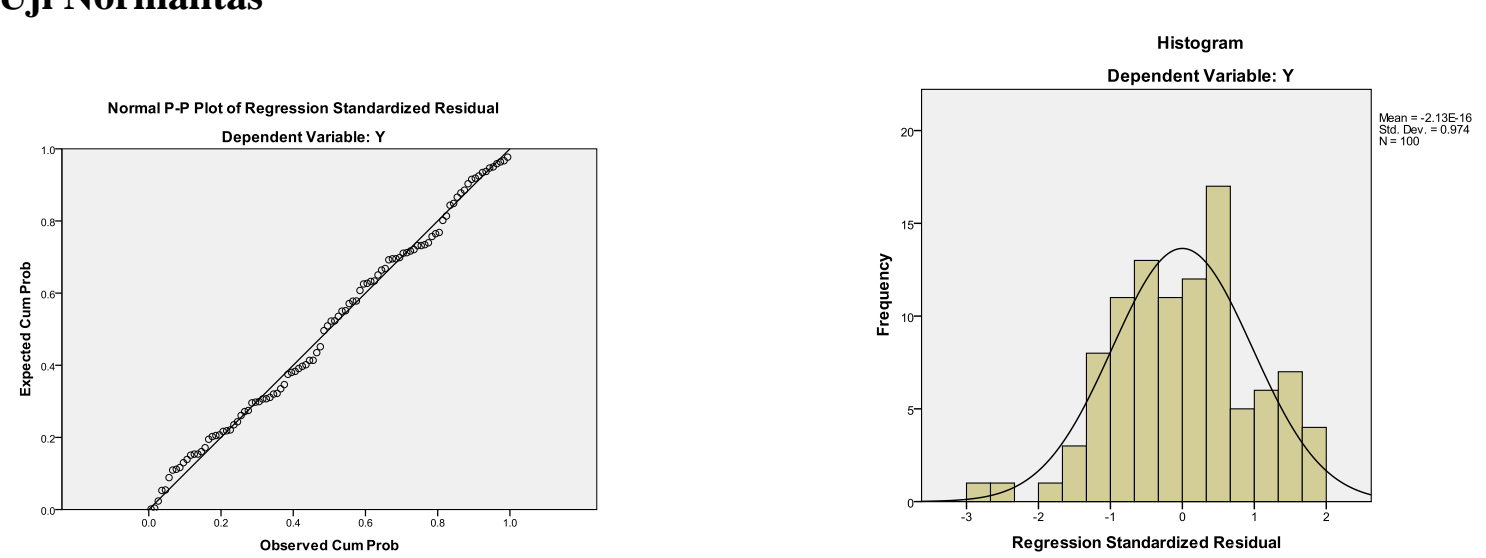

Figure 1. Data Normality Test

In the picture can be seen that the normal plot probability chart that shows the pattern of the normal chart. This can be seen from the points scattered around the normal chart. This is seen from the dots spreading around the diagonal line and its distribution Multicolerity Test Table 5. Multicolerity Test questionnaire was reliable because it was greater than 0.600 .

following the diagonal line. It can therefore be concluded that the regression model is worth agreeing because it meets the assumptions of normality

Coefficients $^{a}$

\begin{tabular}{|c|c|c|c|c|c|c|c|}
\hline \multirow[t]{2}{*}{ Model } & \multicolumn{2}{|c|}{$\begin{array}{c}\text { Unstandardized } \\
\text { Coefficients }\end{array}$} & \multirow{2}{*}{$\begin{array}{c}\begin{array}{c}\text { Standardized } \\
\text { Coefficients }\end{array} \\
\text { Beta }\end{array}$} & \multirow[t]{2}{*}{$\mathrm{t}$} & \multirow[t]{2}{*}{ Sig. } & \multicolumn{2}{|c|}{ Collinearity Statistics } \\
\hline & $\mathrm{B}$ & Std. Error & & & & Tolerance & VIF \\
\hline $1 \quad$ (Constant) & 3.366 & 1.262 & & 2.667 & .009 & & \\
\hline $\mathrm{X} 1$ & -.064 & .150 & -.070 & -.429 & .669 & .301 & 3.317 \\
\hline $\mathrm{X} 2$ & .420 & .163 & .405 & 2.585 & .011 & .328 & 3.045 \\
\hline X3 & -.002 & .126 & -.002 & -.019 & .985 & .572 & 1.749 \\
\hline X4 & .081 & .104 & .080 & .780 & .438 & .763 & 1.311 \\
\hline X5 & .223 & .094 & .229 & 2.387 & .019 & .874 & 1.145 \\
\hline
\end{tabular}

a. Dependent Variable: $Y$

If the total value of all variables is less than 10, there are no indications of multicolineritas, according to the table above. 
Heterokedastisity Test

Table 6. Heterokedastisity Test

\begin{tabular}{|c|c|c|c|c|c|c|}
\hline \multirow{3}{*}{\multicolumn{2}{|c|}{ Model }} & \multicolumn{3}{|c|}{ CoeftIclents $^{\mathrm{a}}$} & \multirow[b]{3}{*}{$t$} & \\
\hline & & \multicolumn{2}{|c|}{ Unstandardized Coefficients } & \multirow{2}{*}{$\begin{array}{c}\begin{array}{c}\text { Standardized } \\
\text { Coefficients }\end{array} \\
\text { Beta }\end{array}$} & & \multirow[b]{2}{*}{ Sig. } \\
\hline & & \multirow{2}{*}{ B 1.644} & \multirow{2}{*}{$\begin{array}{r}\text { Std. Error } \\
.735\end{array}$} & & & \\
\hline \multirow[t]{6}{*}{1} & (Constant) & & & \multirow[b]{2}{*}{-.025} & 2.237 & .028 \\
\hline & $\mathrm{X} 1$ & -.012 & .088 & & \multirow{5}{*}{$\begin{array}{r}-.133 \\
.381 \\
.548 \\
-.523 \\
.173\end{array}$} & \multirow{5}{*}{$\begin{array}{l}.895 \\
.704 \\
.585 \\
.602 \\
.863\end{array}$} \\
\hline & $\mathrm{X} 2$ & .036 & .095 & \multirow{4}{*}{$\begin{array}{r}.068 \\
.074 \\
-.061 \\
.019\end{array}$} & & \\
\hline & X3 & .040 & .073 & & & \\
\hline & $\mathrm{X} 4$ & -.032 & .061 & & & \\
\hline & $\times 5$ & .009 & .054 & & & \\
\hline
\end{tabular}

a. Dependent Variable: ABRESID

From the table above, the probability value is already greater than the alpha value
(0.05), so that in this research model does not contain heterokedastisitas

\section{Test F}

\section{Table 7. Test Result f}

\begin{tabular}{|ll|r|r|r|r|r|}
\hline Model & & Sum of Squares & \multicolumn{1}{|c|}{ df } & Mean Square & F & Sig. \\
\hline 1 & Regression & 209.525 & 5 & 41.905 & 6.058 & $.000^{\text {a }}$ \\
& Residual & 650.185 & 94 & 6.917 & & \\
& Total & 859.710 & 99 & & & \\
\hline
\end{tabular}

a. Predictors: (Constant), X5, X1, X4, X3, X2

b. Dependent Variable: $Y$

Source : Primary data processed, 2019

From the results of the $\mathrm{F}$ test in this study obtained a calculated value of $\mathrm{F}$ of 6,058 with a significance number ( $\mathrm{P}$ value) of 0.000 . With a significance rate of $95 \%(\alpha=0.05)$. A significance number $(\mathrm{P}$ value) of $0.000<0.05$. Or by looking at the value of $\mathrm{F}$, the condition is accepted if $\mathrm{F}$ Calculates $>$ from $\mathrm{F}$ Table. It can be seen that in the calculation of the value of $\mathrm{F}$ Count of 6,058 and the value of F Table of 2,699 which means F Count > of F Table or 6,058 $>2,699$. On the basis of such comparisons, the $\mathrm{HO}$ is rejected or means that variables of reliability, responsiveness, assurance, empathy and physical evidence have a significant influence together on the satisfaction variable.

Multiple Linear Regression Test

Table 8. Multiple Linear Regressions

\begin{tabular}{|c|c|c|c|c|c|c|}
\hline \multicolumn{7}{|c|}{ Coefficients $^{a}$} \\
\hline \multirow{2}{*}{\multicolumn{2}{|c|}{ Model }} & \multicolumn{2}{|c|}{ Unstandardized Coefficients } & $\begin{array}{l}\text { Standardized } \\
\text { Coefficients }\end{array}$ & \multirow[b]{2}{*}{$t$} & \multirow[b]{2}{*}{ Sig. } \\
\hline & & $\mathrm{B}$ & Std. Error & Beta & & \\
\hline \multirow[t]{6}{*}{1} & (Constant) & 3.366 & 1.262 & & 2.667 & .009 \\
\hline & $\mathrm{X} 1$ & -.064 & .150 & -.070 & -.429 & .669 \\
\hline & $\mathrm{X} 2$ & .420 & .163 & .405 & 2.585 & .011 \\
\hline & X3 & -.002 & .126 & -.002 & -.019 & .985 \\
\hline & $\mathrm{X} 4$ & .081 & .104 & .080 & .780 & .438 \\
\hline & $\mathrm{X} 5$ & .223 & .094 & .229 & 2.387 & .019 \\
\hline
\end{tabular}

a. Dependent Variable: $Y$

Sumber : Data yang diolah, 2019 
Based on table 4.8, multiple linear regression equations are obtained as follows:

$$
\mathrm{Y}=-0.070 \mathrm{X} 1+0.405 \mathrm{X} 2-0.002
$$

$\mathrm{X} 3+0.080 \mathrm{X} 4+0.229 \mathrm{X} 5$

\section{Discussion}

\section{H1: Reliability has a significant effect on satisfaction.}

The first hypothetical assertion that Reliability has a significant effect on satisfaction is not proven. This can be indicated by a significance value ( $\mathrm{P}$ Value) of 0.669 greater than 0.05 and a regression coefficient value of -0.070 . It can be concluded that the higher the Reliability, the higher the satisfaction will not be.

This is because customers are not yet fully concerned about the reliability of employees but more concerned in terms of the speed of the funds can quickly exit. In addition, there are some employees or manteri who cheat in customer surveys and request survey services

\section{H2: Responsiveness has a significant effect on satisfaction.}

The second hypothetical statement that Responsiveness has a significant effect on satisfaction is proven. This can be indicated by a significance value ( $P$ Value) of 0.011 smaller than 0.05 and a regression coefficient value of 0.405 . It can be concluded that the higher the Responsiveness, the higher the satisfaction.

This is because workers have a sense of responsibility for the work they receive and have discipline to the work they do so that customers are satisfied with the responsiveness of the employee.

\section{H3: Guarantees have a significant effect on satisfaction.}

The third hypothetical statement that the Guarantee has a significant effect on Koefisien Determinasi $\left(\mathrm{R}^{2}\right)$

Tabel 9. R-Square satisfaction is not proven. This can be indicated by a significance value ( $\mathrm{P}$ Value) of 0.985 greater than 0.05 and a regression coefficient value of -0.002 . It can be concluded that the higher the guarantee, the higher the satisfaction will not be.

This is because customers do not feel guaranteed to loan funds that they submit to the company because so many procedures must be done.

\section{H4: Empathy has a significant effect on satisfaction.}

The fourth hypothetical assertion that empathy has a significant effect on satisfaction is not proven. This can be indicated by a significance value ( $P$ Value) of 0.438 greater than 0.05 and a regression coefficient value of 0.080 . It can be concluded that the higher the empathy, the higher the satisfaction

This is because employees do not yet understand the member's problems and address the issue in the interests of the member and give personal attention to the member. So the customer is not satisfied with the employee.

\section{H5: Physical evidence has a significant effect on satisfaction.}

The second hypothetical assertion that physical evidence has a significant effect on satisfaction is proven. This can be indicated by a significance value ( $\mathrm{P}$ Value) of 0.019 smaller than 0.05 and a regression coefficient value of 0.229 . It can be concluded that the higher the physical evidence, the higher the satisfaction.

This is because customers see the ability to show attractiveness in terms of physical facilities, equipment that supports business performance, as well as employee appearance. So that the customer is satisfied with the employee. 


\begin{tabular}{|l|c|r|r|c|}
\multicolumn{7}{|c|}{ Model Summary } \\
\hline Model & $\mathrm{R}$ & $\mathrm{R}$ Square & $\begin{array}{c}\text { Adjusted R } \\
\text { Square }\end{array}$ & $\begin{array}{c}\text { Std. Error of the } \\
\text { Estimate }\end{array}$ \\
\hline 1 & $.494^{\mathrm{a}}$ & .244 & .203 & 2.62999 \\
\hline
\end{tabular}

a. Predictors: (Constant), X5, X1, X4, X3, X2

When viewed from the R-Square value of 0.203 shows that the proportion of variable influence reliability, responsiveness, assurance, empathy and physical evidence of variable satisfaction by $20.3 \%$. This means that reliability, responsiveness, assurance, empathy and physical evidence have a proportion of satisfaction influenced by $20.3 \%$ while the remaining $79.7 \%$ $(100 \%-20.3 \%)$ influenced by other variables not present in the linear regression model

\section{CONCLUSION AND RECOMMEN- DATION}

Based on the results of the above research and discussion, it can be concluded that reliability has no significant effect on satisfaction. Responsiveness has a significant effect on satisfaction. Guarantees have no significant effect on satisfaction. Empathy has no significant effect on satisfaction. Physical evidence has a significant effect on satisfaction. Based on the conclusions obtained, the proposed advice is to increase satisfaction by providing maximum service to customers. The speed increase in disbursement service to customers can be directly surveyed from customers who want to borrow. Improved facilities services by providing a comfortable waiting room atmosphere to customers who are dating. Increase customer satisfaction by giving attention to customers who come by giving greetings and greetings.

This study only examined reliability, responsiveness, assurance, empathy and physical evidence had a proportion of the influence on satisfaction by $20.3 \%$ while the remaining $79.7 \%$ was influenced by other variables not present in the linear regression model on the Imalez Multy Corp. Cooperative object. It is expected that future research will not only examine the relationship between reliability, responsiveness, assurance, empathy and physical evidence of satisfaction but there are still other variables that affect satisfaction such as product quality, price perception and loyalty

\section{REFERENCES}

Arifin, Sitio dan Tamba Halomoan. 2001. Perusahaan : Teori dan Praktik. Jakarta: Erlangga.

Arikunto, Suharsimi. 2006. Prosedur Penelitian suatu Pendekatan Praktik. Jakarta: Rineka Cipta.

Augusty, Ferdinand. 2006. Metode Penelitian Manajemen. Semarang: Badan Penerbit Universitas Diponegoro.

Azwar, Saifuddin. 2009. Penyusunan Skala Psikologi. Yogyakarta: Pustaka Pelajar.

Chaniago, Arifinal. 1984. Perperusahaan an Indonesia. Bandung: Angkasa Bandung.

Dajan, Anto. 2000. Pengantar Metode Statistik. Jilid Satu. Jakarta. Cetakan Keduapuluh. LP3ES.

Engel. James F., dkk. 1994. Perilaku Konsumen. Cetakan Pertama. Edisi Keenam. Jakarta. Binarupa Aksara.

Kotler, Philip. 2001. Manajemen Pemasaran: Marketing Management; Analisis Perencanaan, Implementasi, dan Pengendalian. Edisi Indonesia. Jilid 1. Jakarta. PT.Prenhallindo. 
Tjiptono, Fandy.2004. Manajemen Jasa. Edisi I. Yogyakarta. Penerbit Andi Offset.

2007. Strategi Pemasaran Edisi Kedua. Yogyakarta: Penerbit Andi.

------. 2008. Strategi Bisnis Pemasaran. Andi Offset: Yogyakarta.

Umar, Husein. 2003. Riset Pemasaran Dan Perilaku Konsumen. Edisi Revisi Jakarta. Gramedia.

Wahyuni, salamah. 2000. Metode Penelitian Bisnis. Edisi 1. Surakarta. Sebelas Maret University Press. 